\title{
CHITON SQUAMOSUS.
}

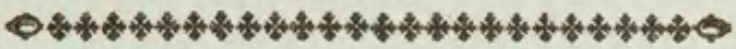

CHARACTER GENERICUS.

Animal Doris.

Tefte plures, longitudinaliter digeftx dorfo incumbentes.

$$
\text { Lin. Syft. Nat. p. } 1106 .
$$

CHARACTER SPECIFICUS, Ec.

CHITON tefta octovalvi femiftriata, margine fquamulofo.

CHITON tefta octovalvi femiftriata, corpore fquamulofo.

$$
\text { Lin. Muf. Ulr. } 465 .
$$

CHITON fquamofus, tefta feptemvalvi.

Chemn. Chiton. t. I. f. 4 .

Rupibus adhæret, ut plurimum, genus Cbiton, patellarum more; continetque fpecies fatis numerofas, quibus fi negarit natura pulchritudinem, miram certe conceffit conformationem, e plurimis quafi zonis teftaceis conftantem. Oras incolit Americanas fpecies quam depinximus, inter maximas habita

fui 
fui generis: color ejus cæruleo-virefcens venulis atomifque obfcurioribus variatur.

Suave eft philofopho contemplari generalem quandam fimilitudinem, quæ interdum mira et manifefta eft in animalibus penitus diverfis, nec ulla affinitate inter fe conjunctis. In hoc ipfo fcilicet Cbitonis genere, tefta qua obducitur animal loricæ fimillima eft qua muniuntur Dafypodes. Quod contigit quoque infectis qua continet Onifci genus; quorum fpecies communis, quæ et officinalis dicitur, hanc ipfam ob caufam nomine Linnæano Onifcus Armadillo nuncupatur. 


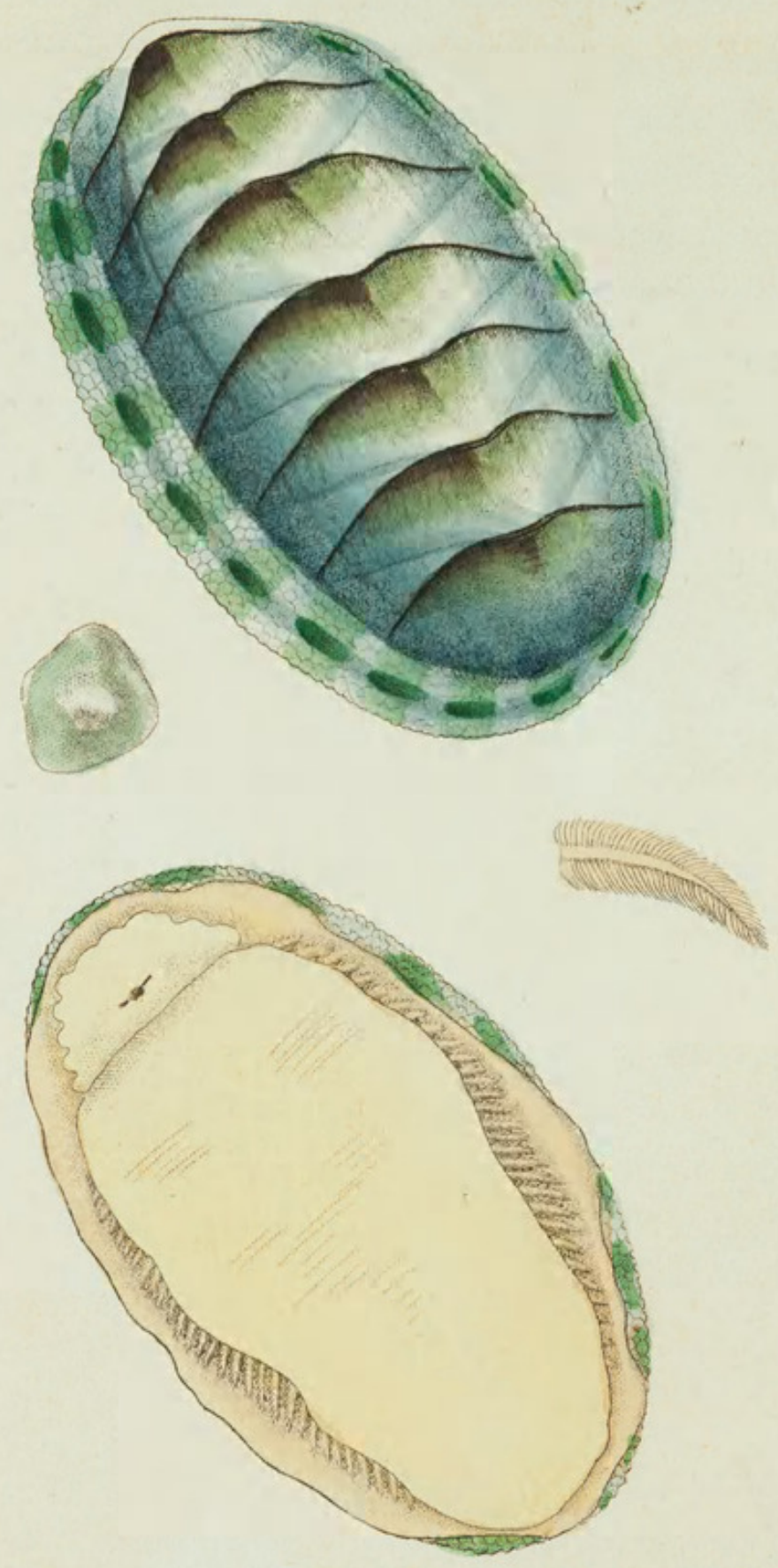
THE

\section{SCALY CHITON.}

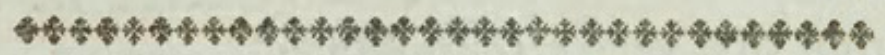

\section{GENERIC CHARACTER.}

Animal refembling a Doris.

Sbell confifting of feveral fegments difpored longitudinally in the back.

I SPECIFIC CHARACTER.

CHITON with the fhell commonly confifting of eight valves; the margin fcaly.

The genus Chiton is generally found adhering to rocks, like fome of the Lepades. The fpecies, which are pretty numerous, are lefs remarkable for beauty than for fingularity of ftructure; being compofed of feveral diftinct fhelly bounds. The fpecies here reprefented is one of the largeft, and is a native of the American coafts. Its general color is a bluein green, variegated with veins and fpecks of darker and lighter colors. It is curious to contemplate the fimilarity in point of general form, which fometimes takes place between animals of the moft diftant tribes, and which have no real affinity to each other. Thus in the prefent genus, the inhabiting animals are covered with an armour refembling that 
of the Dafypodes or Armadillos amongft quadrupeds; and the infects of the genus Onifcus are formed on a fimilar plan; the officinal or common fpecies in particular, which has obtained its trivial name from this very circumftance. 


\section{$2 \mathrm{BHL}$ Biodiversity Heritage Library}

Shaw, George. 1796. "The Scaly Chiton, Chiton squamosus [PI. 257]." The Naturalist's Miscellany 8(LXXXVII), https://doi.org/10.5962/p.310800.

View This Item Online: https://www.biodiversitylibrary.org/item/276320

DOI: https://doi.org/10.5962/p.310800

Permalink: https://www.biodiversitylibrary.org/partpdf/310800

\section{Holding Institution}

Museums Victoria

\section{Sponsored by}

Atlas of Living Australia

\section{Copyright \& Reuse}

Copyright Status: Public domain. The BHL considers that this work is no longer under copyright protection.

This document was created from content at the Biodiversity Heritage Library, the world's largest open access digital library for biodiversity literature and archives. Visit BHL at https://www.biodiversitylibrary.org. 